\section{Geological Society of London : Officers}

Aт the recent annual general meeting of the Geological Society of London the following officers were elected: President, Dr. C. J. Stubblefield; Secretaries, Mr. J. M. Edmonds and Dr. P. A. Sabine; Foreign Secretary, Prof. O. T. Jones; Treasurer, Mr. P. Evans ; Vice-Presidents, Mr. A. J. Butler, Prof. L. Hawkes, Mr. T. C. Nicholas, and Dr. E. I. White.

\section{Institution of Metallurgists : Officers}

ThE following were recently elected to office in the Institution of Metallurgists : President, Prof. A. J. Murphy (College of Aeronautics, Cranfield) ; Presidentelect, W. E. Bardgett (United Steel Companies, Ltd.) ; Vice-Presidents, Dr. W. O. Alexander (Imperial Chemical Industries, Ltd., Metals Division), Prof. J. W. Cuthbertson (University of Nottingham); Hon. Treasurer, Dr. E. G. West (Aluminium Development Association).

\section{Royal Society of South Africa : Officers}

THE following were recently elected to office for 1959 in the Royal Society of South Africa : President, A. J. H. Goodwin; Hon. General Secretary, W. J. Talbot; Hon. Treasurer, Dr. N. Sapeika; Acting Hon. Editor of Transactions, Dr. S. Amdurer ; Hon. Librarian, Dr. J. H. Day. Other Members of Council, Dr. S. H. Haughton, Dr. F. G. Holliman, Dr. W. E. Isaac, Dr. R. F. Lawrence, Dr. R. H. Marloth, Dr. S. M. Naudé, Dr. S. H. Skaife, Dr. R. H. Stoy, and Dr. C. L. Wieht.

\section{The Night Sky in June}

New moon occurs on June 6d. 11h. 53m. U.T. and full moon on June $20 \mathrm{~d} .20 \mathrm{~h} .00 \mathrm{~m}$. The following conjunctions with the Moon take place: June 10d. 15h., Venus $7^{\circ} \mathrm{N}$.; June 10d. 18h., Mars $6^{\circ} \mathrm{N}$; June 18d. 11h., Jupiter $3^{\circ}$ S.; June 2ld. 05h., Saturn $4^{\circ} \mathrm{S}$. In addition to these conjunctions with the Moon, Venus is in conjunction with Mars on June 14d. 13h., Venus being $0 \cdot 8^{\circ} \mathrm{N}$., and Mercury with Pollux on June 24d. 09m., Mercury being $5 \cdot 0^{\circ} \mathrm{S}$. Mercury will be visible for a short time after sunset during the second half of the month. Venus is an evening star, visible in the south-west after sunset. Conditions are favourable for observation. Venus sets at $23 \mathrm{~h} .25 \mathrm{~m}$., 23h. $05 \mathrm{~m}$. and $22 \mathrm{~h} .30 \mathrm{~m}$. on June 1, 15 and 30, respectively; its stellar magnitude is $-\mathbf{3 \cdot 9}$. Its distance decreases during the month from 82 to 60 million miles and the visible portion of the apparent disk decreases from 0.607 to 0.455 . Mars is in Cancer during the month. It sets at $23 \mathrm{~h} .30 \mathrm{~m} ., 23 \mathrm{~h} .00 \mathrm{~m}$. and $22 \mathrm{~h}$. $15 \mathrm{~m}$. at the beginning, middle and end of the month, respectively. Its stellar magnitude is about +1.9 ; it is rapidly approaching conjunction, and is low in the west after sunset. Jupiter sets at $3 \mathrm{~h} .20 \mathrm{~m} ., 2 \mathrm{~h} .20 \mathrm{~m}$. and $1 \mathrm{~h}$. $10 \mathrm{~m}$. on June 1,15 and 30 , respectively. It is in retrograde motion in Libra. The stellar magnitude of Jupiter is $-2 \cdot 0$; its distance is approximately 420 million miles. Saturn is in Sagittarius, rising at $2 \mathrm{lh} .55 \mathrm{~m} ., 20 \mathrm{~h} .55 \mathrm{~m}$. and $19 \mathrm{~h} .40 \mathrm{~m}$. at the beginning, middle and end of the month, respectively. Its stellar magnitude is $+0 \cdot 3$ and its distance is approximately 850 million miles. There is one occultation of a star brighter than magnitude 6 visible at Greenwich : June 1ld. 21h. $21 \cdot 2 \mathrm{~m}$., 162 B. Vir. $(D)$. $D$ refers to disappearance. The summer solstice occurs on June 22d. $04 \mathrm{~h}$.

\section{Announcements}

DR. LouIs Essen, a senior principal scientific officer at the National Physical Laboratory, has been awarded the A. S. Popov's Gold Medal by the Academy of Sciences of the U.S.S.R. This award is for the most distinguished scientific work in the field of radio-engineoring performed during the period 1956-58. Dr. Essen has also recently received the first Wolfe Award of the Department of Scientific and Industrial Research (see Nature, 183, 930; 1959). The work of scientists from all countries is considered, but this is the first time that it has been awarded to a scientist outside the Soviet Union.

Prof. W. M. Elisasser, professor of theoretical physics at the Scripps Institution of Oceanography and the University of California, La Jolla, California, has been awarded the William Bowie Medal. The Medal is awarded for outstanding contributions to the geophysical sciences.

Dr. Robert T. PARKer has been appointed head of the Banbury and Geneva offices of the Aluminium Laboratories, Ltd., in succession to Mr. R. D. Hamer.

Dr. Herman H. Goldstine has been appointed resident manager of the Lamb Estate Research Center of the International Business Machines Corporation, Cortlandt, New York. As resident manager, he will be responsible for IBM research on business theory, psychology, programming, information theory, mathematics, pattern recognition and operational research. Dr. H. J. Greenberg has been appointed manager of the Mathematics Theory Department of the Lamb Estate Research Center.

The Fulmer Research Institute, at Stoke Poges, Bucks., will hold an open day on July 16. Attendance will be by invitation only.

THE autumn meeting of the Radiofrequency Spectroscopy Group, which will be held at the Clarendon Laboratory, Oxford, during September $17-18$, is to be devoted to the radio-frequency spectroscopy of free atoms and molecules, with sessions on atomic beam and optical methods, microwave gaseous spectroscopy and the measurement of fundamental constants by radio-frequency methods. Registration forms (with requests for accommodation, which must be returned before July 1) can be obtained from Prof. B. Bleaney, Clarendon Laboratory, Oxford.

AN International Oceanographic Congress, sponsored by the American Association for the Advancement of Science in co-operation with Unesco and the International Council of Scientific Unions, will be held in the United Nations building, New York, during August 30-September 12. Further information can be obtained from Dr. Mary Sears, Woods Hole Oceanographic Institution, Mass.

The Ninth International Botanical Congress will be held in Montreal, during August 19-29, at the University of Montreal, McGill University and Sir George Williams College, under the auspices of the Canadian Department of Agriculture. Dr. W. P. Thompson, president of the University of Saskatchewan, has been elected president of the Congress. The programme will be conducted in sixteen sections and will deal with all aspects of botany in its broadest sense, including plant production, breeding, and protection and their implications for agriculture and forestry. Inquiries should be directed to the secretary general, Dr. C. Frankton, Ninth International Botanical Congress, Science Service Building, Ottawa, Ontario. 